\title{
Dampak Kesehatan Anak Pada Periode Embrio, Janin, Bayi dan Usia Sekolah dengan Ayah Perokok
}

\author{
Fitra Duhita ${ }^{1}$, Novi Indah Rahmawati ${ }^{2}$ \\ Prodi DIV Kebidanan Sekolah Vokasi UGM ${ }^{1,2}$ \\ fitra.duhita@ugm.ac.id
}

Submitted 19 Desember 2018 Revised 11 Januari 2019 Accepted 22 Januari 2019

\section{ABSTRAK}

Latar Belakang: Sekitar 60,3\% perokok di Indonesia adalah laki-laki, dan hanya $1 \%$ saja pada perempuan. Hal ini disebabkan nilai budaya bahwa perempuan perokok adalah tabu. Tetapi laki-laki perokok dianggap sebagai simbol maskulinisme, salah satu bentuk interaksi sosial dan cara untuk menghilangkan perasaan negatif. Namun jika kebiasaan merokok pada laki-laki lanjut hingga mereka menjadi ayah, maka akan membawa dampak negatif pada anaknya.

Tujuan: Penelitian ini bertujuan untuk mengetahui dampak yang terjadi pada anak jika ayah seorang perokok.

Metode: Artikel ini merupakan hasil telaah berbagai referensi penelitian yang berkaitan/ mengaitkan antara dampak rokok secara umum dan dampak ayah perokok secara khusus terhadap hasil konsepsi, kesehatan serta tumbuh kembang anak.
Hasil: Telaah artikel menunjukkan bahwa paparan asap rokok saat anak pada periode embrio dapat mengakibatkan terjadinya abortus spontan; pada periode fetus mengakibatkan persalinan prematur dan berat badan bayi rendah; pada periode bayi meningkatnya risiko asma dan keterlambatan perkembangan mental. Keadaan ini disebabkan komponen kimia yang terkandung di dalam asap rokok yang berbahaya. Selain itu, anak yang memiliki ayah perokok memiliki risiko 3 kali lebih besar untuk menjadi perokok juga pada periode remajanya. Lebih lanjut, kondisi ini menyebabkan mata rantai perokok semakin sulit diputuskan, dan berdampak negatif hingga generasi selanjutnya.

Kesimpulan: Berdasarkan hasil telaah artikel ini, penting bagi tenaga kesehatan untuk melakukan upaya pendidikan kesehatan kepada setiap ayah dalam keluarga agar lebih bijak dalam merokok.

Kata Kunci: ayah perokok; dampak anak perokok pasif

ABSTRACT

Background: Almost 60,3\% of smoker in Indonesia are men, and only $1 \%$ in women. That is caused by smoking for a women as a taboo. But smoking for a men as a symbol of masculineism, manner in social interaction with their community and best choice to ignoring negative feeling. If smoking habit in men continuing until they become a father, its bring negative effect for their children.

Objective: This study aim to know kind of effect to his children while father as a smoker

Methods: This is literatur review from research article which discuss about the effect of cigarete smoke also father as smoker to children while in conception periode, future health and development.
Result: The review showed that exposure of the smoke in embrionic periode can cause spontaneouse abortion; in foetal periode cause preterm delivery and low birth weight baby; in infant periode increase risk of asthma and mental development delay. All of that condition is caused by chemical compounds of the smoke. In other hand, children who have father whose smoking are risk three times greater to be smoker too in the future. Furthermore, it cause the chain of smoker will difficult to cut and bring negative impact for next generation.

Conclusion: From this review's result, its important for primary health care provider to promote health education for every father in the family to wise while smoking.

Keywords: smoking father; secondhand smoke children effect 


\section{PENDAHULUAN}

Data Kementerian Kesehatan menunjukkan bahwa sejak tahun 1995 sd 2013, terjadi peningkatan perbandingan penduduk perokok dan bukan perokok semula 1:3 menjadi 2:3 (Depkes RI, 2016). Sebanyak 36,1\% populasi penduduk di Indonesia adalah perokok (WHO South East Asia, 2011). Angka tersebut menjadikan Indonesia sebagai negara dengan pervalensi merokok yang cukup tinggi di dunia, dan menjadi salah satu dari lima negara yang menjadi fokus perhatian WHO Bloomberg Initiative to Reduce Tobacco Use. Melalui program tersebut, WHO bersama dengan Kementerian Kesehatan Republik Indonesia telah melakukan berbagai upaya untuk menurunkan jumlah perokok di Indonesia(WHO, 2015).

Keuntungan yang didapatkan dari merokok tidak melebihi kerugian yang didapatkan, terutama terhadap kesehatan. Komponen kimia yang dihasilkan dari asap rokok dapat masuk ke dalam tubuh melalui asap hasil pembakaran rokok, terkumpul ke dalam seminal plasma melalui proses difusi dan transport aktif. Selanjutnya dapat menyebabkan gangguan fungsi organ, dan dalam jangka panjang berdampak pada kerusakan organ (Cui, et al., 2016). Dampak negatif ini tidak hanya dialami oleh perokok itu sendiri, namun juga berdampak pada orangorang disekitar perokok.

Perokok di Indonesia masih didominasi oleh laki-laki, yaitu 60,3\%, sedangkan perempuan masih sebesar 1,2\% (BPS, 2015). Meskipun jumlah perempuan perokok mengalami peningkatan setiap tahun, namun besarannya belum menunjukkan angka yang signifikan. Nilai maskulinisme dari rokok ini mengakibatkan lahirnya persepsi tabu bagi perempuan untuk merokok. Namun sebaliknya, bagi laki-laki merokok merupakan salah satu simbol interaksi dengan lingkungannya. Selain itu mayoritas laki-laki merokok karena menghisap rokok dirasa dapat menurunkan perasaan negatif, sehingga merasa lebih tenang dalam menghadapi permasalahan (Darwin, 2007).

Tanpa disadari jika kebiasaan merokok berlanjut hingga laki-laki tersebut berperan sebagai ayah, dapat berdampak pada kualitas kesehatan keluarga, terutama anak. Ayah sebagai simbol pengayoman keluarga dan suri tauladan utama bagi anak. Sehingga kokohnya keluarga tidak terlepas oleh peran ayah dalam mewujudkan kesehatan keluarga, salah satunya kesadaran untuk menyediakan lingkungan yang bebas asap rokok bagi anakanaknya sejak periode pra konsepsi hingga masa dewasa (Yogman \& Garfield, 2016).

\section{METODE}

Artikel ini adalah hasil telaah literatur (literatur review) tentang berbagai dampak kesehatan yang ditimbulkan pada anak sejak periode janin hingga usia sekolah, jika ayah seorang perokok. Ayah perokok yang dimaksud dalam artikel ini adalah ayah yang memberikan paparan asap rokok secara langsung pada keluarganya (resident father' smoking) dan bukan ayah yang tidak tinggal serumah. Terdapat berbagai jenis rokok, antara lain rokok tembakau, pipe, cigar, shisha, dll. Pada artikel ini rokok yang dimaksud adalah rokok tembakau.

\section{HASIL DAN PEMBAHASAN}

\section{Asap rokok dan komponen kimia penyusunnya}

Asap hasil pembakaran rokok terdiri atas 3 jenis, yaitu asap dari bara rokok (sidestream smoke), asap yang dihisap oleh perokok (mainstream smoke) dan asap yang dihembuskan oleh perokok (exhaled mainstream smoke). Selain dihisap oleh perokok sendiri, asap hasil pembakaran rokok juga akan menjadi asap bebas di lingkungan perokok, biasa disebut asap rokok pasif (passive smokel secondhand smoke) (Harlev, et al., 2015; Department of Health and Human Services, 2006). 


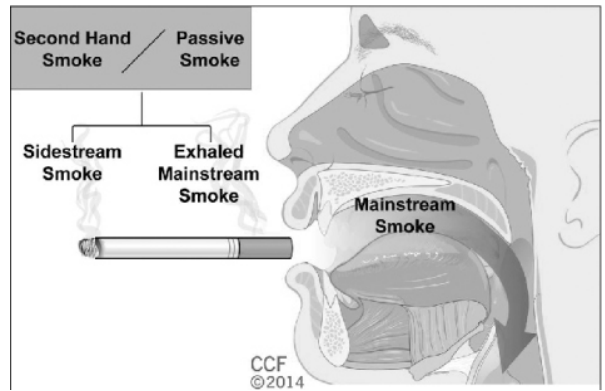

Gambar 1. Jenis asap yang dihasilkan oleh perokok (Cui, et al., 2016)

International Agency for Research on Cancer (IARC) menjelaskan bahwa terdapat sekitar 4.000 komponen kimia yang dihasilkan dari asap rokok. Studi kualitatif menujukkan bahwa komponen kimia yang dihasilkan oleh mainstream smoke, sidestream smoke dan secondhand smoke hampir sama. Sekitar 250 komponen diantaranya bersifat karsinogenik.

\section{Dampak paparan asap rokok saat anak pada periode embrio}

Kebiasaan merokok pada laki-laki berkaitan dengan infertilitas (Department of Health and Human Services, 2006). Perokok aktif terutama kelompok yang menghisap lebih dari 9 batang rokok dalam 1 hari mengalami penurunan kualitas sperma meliputi penurunan motilitas sperma, abnormalitas morfologi sperma bagian kepala, dan penurunan viabilitas sperma secara signifikan (Cui, et al., 2016). Perbandingan kondisi sperma dilihat melalui pemeriksaan mikroskopis sperma (gambar perbesaran $20 \mathrm{kali}$ ), antara kelompok perokok dan bukan perokok tampak pada gambar berikut:

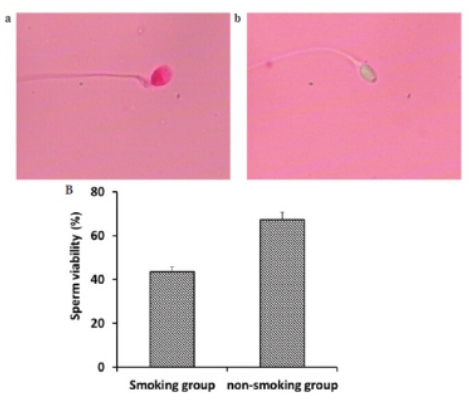

\footnotetext{
Gambar 2. Perbandingan viabilitas sperma antara kelompok perokok $(n=920)$ dan kelompok bukan perokok $(n=298)$. (A)a.
}

Sperma yang tidak viabel tergambar abnormalitas morfologi berupa stained head; (A)b. Sperma viabel tampak unstained head. (B) Kelompok perokok mengalami penurunan viabilitas sperma secara signifikan (Cui, et al., 2016)

Penurunan kualitas morfologi sperma, selain dapat menyebabkan infertilitas juga dapat menjadi penyebab terjadinya abortus spontan. Abortus adalah keluarnya hasil konsepsi sebelum usia kehamilan 20 minggu. Penyebab terjadinya abortus salah satunya adalah hasil konsepsi yang tidak dapat berkembang dengan baik. Merokok juga menyebabkan kerusakan pada DNA yang dibawa oleh sel sperma (Cui, et al., 2016). Kerusakan kromosom ini juga dapat menjadi penyebab terjadinya abortus, karena kromosom yang tidak baik, akan menimbulkan reaksi rejeksi spontan dari tubuh maternal. Sehingga embrio tidak mampu berkembang lebih lanjut menjadi janin. Hasil konsepsi yang berkualitas, sangat dipengaruhi oleh kualitas sel telur baik dari laki-laki (sperma) dan perempuan (ovum) yang baik (Cunningham, et al., 2010).

Selain itu, dampak bagi anak pada periode embrio dengan ayah perokok dapat melalui mekanisme paparan asap rokok terhadap istri yang sedang hamil. Ibu hamil yang terpapar asap rokok atau sebagai perokok pasif (secondhand smoke exposure) meningkatkan risiko sebesar $11 \%$ untuk mengalami abortus (Pineles, et al., 2014). Hasil studi lain menunjukkan bahwa pasangan suami istri dengan ayah perokok berisiko 3,6 kali lebih besar mengalami abortus spontan. Dan jika ayah dan ibu perokok, risiko akan meningkat menjadi 4,6 kali lebih besar dibandingkan dengan pasangan yang keduanya bukan perokok (Blanco-Munoz, et al., 2009). Hal ini disebabkan unsur kimia yang ada di dalam asap rokok, yaitu unsur nikotine, $\mathrm{CO}$ dan mutagen lain.

Nikotin menyebabkan vasokonstriksi pembuluh darah, termasuk pembuluh darah uteroplasenta, berakibat pada penurunan 
sirkulasi darah fetomaternal (Economides \& Braithwaite, 1994). Sirkulasi darah fetomaternal sangat menentukan kecukupan oksigen dan nutrisi janin. Sehingga jika terjadi penurunan sirkulasi, maka akan berpengaruh terhadap perkembangan embrio (Kliman, 1999) Embrio yang tidak mampu berkembang dengan baik hingga usia 20 minggu, maka dapat menyebabkan terjadinya abortus spontan (Cunningham, et al., 2010).

\section{Dampak paparan asap rokok saat anak pada periode janin}

Periode janin adalah masa pertumbuhan untuk penyempurnaan morfologi organ dan perkembangan fungsinya. Jika ibu hamil pada periode tersebut terpapar asap rokok, maka dampak yang ditimbulkan juga terjadi pada janin yang dikandungnya, antara lain:

a. Kelainan Kongenital

Komponen mutagen yang terkandung pada asap rokok mengakibatkan munculnya reaksi teratogenik (Cunningham, et al., 2010). Reaksi teratogenik dini akan berdampak terhadap terjadinya abortus dan kematian perinatal, sedangkan reaksi teratogenik pada periode organogenesis akan menyebabkan terjadinya kelainan kongenital pada anak yang dilahirkan (Department of Health and Human Services, 2006). Selain itu penyebab berbagai kelainan tersebut adalah efek genotoksin dan karsinogen dari tembakau (Leonardi-Bee, et al., 2011).

Kelainan yang terjadi akibat ibu terpapar asap rokok sejak periode hamil antara lain atresia anorectal, neural tube defects (NTD), bibir sumbing (orofacial cleft), omfalokel, hipospadia, atresia esofagus, hernia diafragmatika, serta congenital heart defect (Miller, et al., 2009; Wang, et al., 2014; Zhang, et al., 2011; Feldkamp, et al., 2014; Carmichael, et al., 2005; Wong-Gibbons, et al., 2008).

\section{b. Bayilahir dengan BBLR}

Bayi berat lahir rendah (BBLR) adalah bayi yang lahir dengan berat kurang dari 2500 gram (Cunningham, et al., 2010) Bayi dengan BBLR memiliki risiko tinggi untuk mengalami morbiditas dan mortalitas dini. BBLR yang terjadi pada ibu hamil yang mengalami toksisitas tembakau dibedakan atas BBLR akibat gangguan pertumbuhan dan BBLR akibat kelahiran preterm (Malik, et al., 2008). Perempuan hamil bukan perokok yang menjadi perokok pasif lebih berisiko melahirkan bayi dengan BBLR akibat gangguang pertumbuhan karena peningkatan kadar karbon monoksida (CO) dalam sirkulasi maternal (Singh \& Scott, 1984) dan BBLR akibat kelahiran preterm karena penurunan progesteron (Spitz, 2003) Selain itu BBLR preterm juga terjadi akibat KPD (Malik, et al., 2008)

Mekanisme BBLR akibat peningkatan kadar karbon monoksida dijelaskan sebagai berikut. Karbon monoksida (CO) hasil pembakaran asap rokok mengakibatkan oksigen $(\mathrm{O} 2)$ yang diedarkan melalui sirkulasi darah menuju seluruh tubuh menurun. Karena hemoglobin yang seharusnya mengikat oksigen saja, berubah menjadi mengikat CO membentuk carboxyhemoglobin $(\mathrm{COHb})$. Hal ini menyebabkan terjadinya fetotoxicity yang termanifestasi dalam bentuk hipoksia janin. Kondisi ini terjadi sangat berkaitan dengan terjadinya gangguan pertumbuhan janin (Singh \& Scott, 1984). Bayi dengan gangguan pertumbuhan berisiko mengalami berat badan lahir rendah (Gardosi, 2005).

Peningkatan kadar CO pada sirkulasi darah ibu perokok pasif juga menyebabkan penurunan viabilitas hasil konsepsi melalui mekanisme hipoksia janin (Singh \& Scott, 1984). Penurunan viabilitas tersebut karena bayi terlahir sebelum mampu hidup diluar kandungan.

Kondisi lain akibat merokok yang 
dapat menurunkan viabilitas hasil konsepsi adalah penurunan kadar progesteron. Kombinasi nikotin, kotinin dan anabasin menghambat sintesis progesteron (Gocze, et al., 1999). Padahal progesteron memiliki peranan penting terhadap perkembangan hasil konsepsi pada periode embrio, salah satunya adalah mempertahankan kehamilan terus berkembang (Perkins, 2000). Kadar progesteron yang rendah pada periode kahamilan ( $<45 \mathrm{nmol} / \mathrm{L})$ menjadi faktor prediktor yang tinggi bahwa kehamilan tersebut nonviable (sensitifitas 88,6\%; spesifisitas 87,5\%) (Spitz, 2003).

Perempuan sebagai perokok pasif juga berisiko melahirkan bayi BBLR karena terjadi inisiasi persalinan dini akibat ketuban pecah dini (KPD). KPD adalah pecahnya ketuban sebelum munculnya tanda-tanda persalinan. Nikotin dan komponen kimia yang terkandung dalam rokok menyebabkan penurunan kolagen penyusun selaput ketuban (Malik, et al., $2008)$. Penipisan kolagen juga menyebabkan selaput ketuban menipis, kemudian pecah. Salah satu mekanisme yang menyebabkan rendahnya jaringan
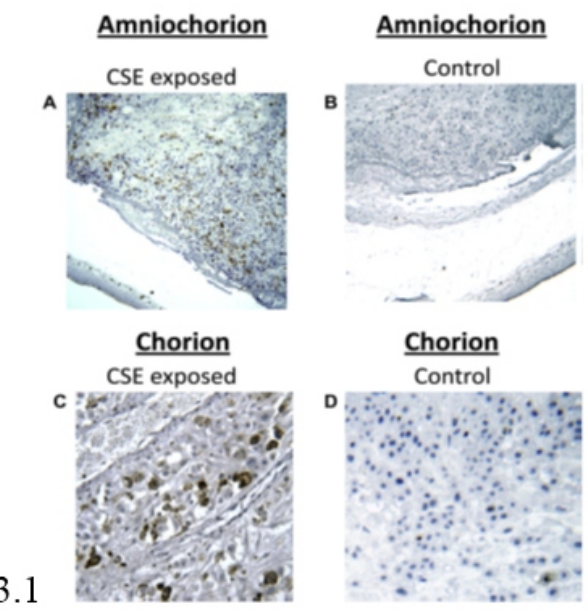

kolagen maupun sel-sel lain penyusun selaput ketuban adalah terjadinya stres oksidatif (Menon, et al., 2011).

Menon dkk dalam penelitiannya membandingkan 2 kelompok, yaitu perlakuan dan kontrol sampel selaput ketuban (korion). Kelompok perlakuan adalah sampel selaput ketuban yang terpapar ekstrak rokok, dengan komponen kimia per batang rokok adalah $26 \mathrm{mg}$ tar dan 1,7 mg nikotin. Hasil penelitian tersebut menunjukkan bahwa selaput ketuban yang terpapar komponen kimia rokok mengalami stres oksidatif yang ditunjukkan dengan meningkatnya produksi biomarker F2-isoprostone (F2IsoP). Kenaikan F2-IsoP pada kelompok perlakuan hampir 2 kali lipat dibandingkan kelompok kontrol (242.8 \pm 79.3 vs. $131.5 \pm 53.1 \mathrm{pg} / \mathrm{ml} / \mathrm{mg}$ protein; $\mathrm{p}<$ 0.001). Lebih lanjut tingginya biomarker F2-IsoP ini berhubungan dengan terjadinya kerusakan sel membran korion (chorion apoptosis), yang ditandai dengan jumlah caspase dan fragmentation of nuclei yang lebih banyak pada kelompok perlakuan, sebagaimana tampak pada gambar berikut (Menon, et al., 2011):

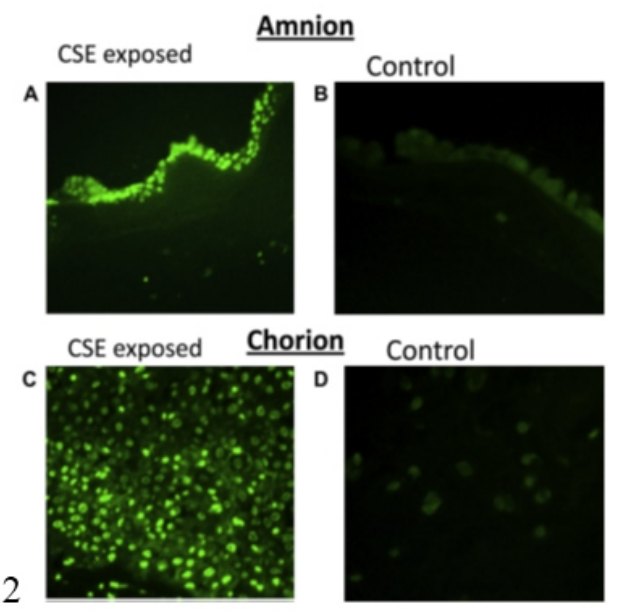

Gambar 3.

3.1 Immunohistochemistry of caspase. Caspase (Cysteine Aspartate Specific Protease) adalah enzim protease yang berperan penting sebagai eksekutor kerusakan sel. Pada selaput ketuban (chorion) maupun air ketuban (amniochorion) yang terpapar ekstrak rokok tampak memiliki jumlah caspase yang lebih banyak (Gambar A [dengan pembesaran 10x] dan C [dengan pembesaran 40x])

3.2 TUNEL staining for fragmentation of nuclei. Gambar A dan C (kelompok perlakuan) nampak fragmen inti sel (penanda warna hijau terang) pada selaput ketuban maupun air ketuban lebih banyak dibandingkan pada gambar B dan D (kelompok kontrol) (Menon, et al., 2011) 
Gambar 3 berasal dari penelitian serupa. Banyaknya Caspase (gambar 3.1) pada kelompok perlakuan dibandingkan dengan jumlah kerusakan sel (gambar 3.2) yang ditandai dengan jumlah fragmen inti sel (fragmentation of nuclei) menunjukkan hasil yang kosisten. Pada kelompok perlakuan diketahui jumlah fragmen inti sel lebih banyak dibandingkan dengan kelompok kontrol (Menon, et al., 2011).

Kondisi kerusakan sel jaringan ini menyebabkan selaput ketuban menjadi lebih mudah untuk ruptur akibat invasi bakteri. Jika ibu hamil mengalami KPD, maka upaya konservatif (mempertahankan persalinan) jangka panjang akan berdampak tidak baik bagi ibu maupun janin Sehingga bayi akan terlahir lebih awal dari waktu yang seharusnya. Karena ketika kantong ketuban telah pecah, maka terdapat porte d'entree mikroba terbuka untuk menginvasi hasil konsepsi maupun maternal. Kelahiran janin pada periode preterm meningkatkan risiko bayi lahir dengan berat lahir yang kurang mencukupi. Bayi BBLR memiliki risiko lebih tinggi mengalami berbagai kondisi yang berdampak pada morbiditas dan mortalitas neonatal (Verma, et al., 2006).

\section{Dampak paparan asap rokok saat anak pada periode bayi}

Periode bayi adalah segera setelah bayi lahir hingga berusia 12 bulan. Dampak paparan asap rokok pada periode bayi ini bisa merupakan komplikasi sejak periode kongenital akibat dari ibu yang terpapar asap rokok pada periode kehamilannya, ataupun bayi yang setelah lahir terpapar langsung oleh asap rokok.

a. Dampak bagi bayi akibat paparan sejak periode kehamilan

Lee pada penelitiannya terhadap 414 ibu yang selama hamil terpapar asap rokok secara pasif, diketahui berdampak negatif pada perkembangan anak yang dikandungnya, dibandingkan dengan ibu hamil yang tidak terpapar. Perkembangan anak diukur dengan menggunakan Bayley Scales of Infant Development. Hasil penelitian menunjukkan bahwa pada kelompok dengan ibu yang terpapar asam rokok, saat kehamilan berusia 6 bulan, diketahui adanya peningkatan risiko keterlambatan perkembangan mental (mental developmental delay) (Lee, et al., 2011). Keterlambatan perkembangan mental ini adalah dampak yang tidak kasat mata, yang seringkali terabaikan oleh masyarakat awam. Padahal risiko yang ditimbulkan dari keadaan ini berlanjut hingga anak berusia dewasa.

Selain itu, ayah perokok meningkatkan risiko sebesar 1,68 kali terjadinya non-allergic erly-onset asthma pada bayi. Risiko tersebut meningkat menjadi 3,24 kali jika kebiasaan merokok ayah telah dimulai sejak berusia sebelum 15 tahun (Svanes, et al., 2017). Mekanisme terjadinya gangguan ini merupakan dampak lanjutan dari kelainan gangguan pertumbuhan dan perkembangan sistem pernafasan pada periode janin, yaitu fetotoxicity akibat unsur kimia pada rokok (Singh \& Scott, 1984).

b. Dampak bagi bayi akibat paparan langsung

Sebuah studi systematic review dan meta-analysis terhadap 60 artikel didapatkan bahwa bayi dengan orang tua perokok atau di dalam rumah terdapat perokok, maka secara signifikan berisiko infeksi pernafasan bawah (OR 1,22) pada bayi hingga usia 2 tahun. Pada studi yang sama, bayi sebagai perokok pasif juga berhubungan dengan terjadinya infeksi pernafasan lain, yaitu infeksi saluran pernafasan bawah unspesifik $(\mathrm{p}<0,00001)$, bronkitis $(p=0,0001)$, bronkiolitis $(p=0,0001)$ dan infeksi saluran pernafasan akut ( $\mathrm{p}=0$,001) (John, et al., 2011). Namun dalam studi ini tidak disebutkan berapa lama intensitas keterpaparan anak yang berdampak pada munculnya risiko infeksi gangguan pernafasan tersebut. 
Perlu menjadi perhatian lebih juga bagi orang tua maupun anggota keluarga yang memiliki anak yang terinfeksi influenza. Sebuah studi terhadap 117 anak yang terkonfirmasi terinfeksi influenza menunjukkan bahwa, anak yang terapapar perokok pasif berisiko 4,7 kali untuk dirawat pada unit intensive care dan $70 \%$ lebih lama dalam menjalani perawatan akibat gangguan sistem pernafasan (Wilson, et al., 2013).

\section{Dampak paparan asap rokok saat anak pada periode sekolah}

Data Riskesdas menunjukkan bahwa terjadi peningkatan prevalensi remaja usia 1619 tahun) yang merokok sebesar 3 kali, semula pada tahun 1995 sebesar 7,1\% menjadi 20,5\% pada tahun 2013. Selain itu, usia remaja perokok juga semakin dini. Perokok pada remaja usia 10-14 tahun semula pada tahun 1995 sebesar $8,9 \%$ menjadi $18 \%$ pada tahun 2013 (Depkes RI, 2016). Dampak anak yang terpapar asap rokok pada usia sekolah terhadap kesehatan sama dengan saat anak terpapar pada usia bayi, yaitu gangguan pernafasan dan pertumbuhan. Sedangkan dampak spesifik pada periode ini adalah pada perkembangan perilaku anak.

Berdasarkan teori Schor and Menaghan's Model of the Social Context of Child Health, menjelaskan bahwa lingkungan dan keluarga berfungsi sebagai faktor penentu utama dari karakter anak, pengembangan dan hasil perkembangan anak (Ball, et al., 2007). Gilman dalam studinya menjelaskan bahwa anak dengan ayah perokok, hampir 3 kali berisiko anak turut berperilaku sebagai perokok pada periode remajanya. Jika yang perokok ayah dan ibu, maka risiko perilaku merokok dapat terjadi pada anak laki-laki maupun perempuan. Namun jika ayah saja yang merokok, maka risiko perilaku merokok hanya terjadi pada anak laki-lakinya saja. Perilaku merokok anak ini rata-rata muncul pada usia 13 tahun (Gilman, et al., 2009). Usia 13 tahun adalah usia anak memasuki usia remaja. Karakteristik perkembangan anak pada usia tersebut adalah mulai mencoba hal yang baru tanpa disertai penalaran yang memadai dampak dan manfaat yang akan diperoleh. Sehingga jika anak sejak usia dini melihat perilaku merokok tanpa diberikan pemahaman kerugian dari merokok, maka mereka akan memiliki kecenderungan untuk mencoba merokok.

Ayah perokok dapat menginisiasi anak juga perokok hanya jika ayah adalah seorang perokok aktif. Jika ayah memiliki riwayat merokok kemudian dapat berhenti, maka risiko anak perokok sama rendahnya pada anak dengan ayah bukan perokok (Gilman, et al., 2009). Sehingga upaya promosi kesehatan pada keluarga yang efektif masih memungkinkan untuk memutuskan mata rantai perokok dan dampaknya.

Ayah secara naluriah siap bekerja keras untuk memenuhi kebutuhan dan kebahagiaan keluarga. Namun menjadi kontradiktif jika ayah sebagai perokok. Kerja keras yang telah dilakukan untuk keluarga kurang dapat bermanfaat secara optimum untuk mensejahterakan keluarganya, karena harus mengeluarkan banyak biaya untuk pengobatan akibat penyakit yang ditimbulkan oleh kebiasaan merokoknya.

\section{PENUTUP}

Ayah perokok menyebabkan terjadinya dampak negatif pada anak-anaknya, baik dampak bagi kesehatan maupun dampak sosial. Dampak negatif bagi kesehatan terjadi sejak anak pada masa embrio hingga prasekolah. Sedangkan dampak sosial terjadi saat anak berusia prasekolah hingga dewasa, yaitu salah satunya terjadi transmisi perilaku merokok.

Transmisi perilaku merokok lintas generasi (intergenerational transmission) ini dapat melanggengkan rantai perokok di Indonesia. Lebih lanjut hal ini dapat semakin memperparah dampak negatif merokok di setiap siklus kehidupan. Oleh karena itu, penting disadari bagi setiap ayah untuk lebih bijak dalam berperilaku merokok. 


\section{KETERBATASAN}

Penulis masih belum dapat menemukan referensi rujukan tentang ukuran lama/durasi maupun intesitas keterpaparan asap rokok yang dapat berdampak pada gangguan kesehatan anak.

\section{DAFTAR RUJUKAN}

Ball, J., Moselle, K. \& Pedersen, S (2007) Father's Involvement as a Determinant of Child Health, Canada: Public Health Agency of Canada.

Blanco-Munoz, J., Torres-Sanchez, L. \& LopezCarrilo, L (2009) Exposure to Maternal and Paternal Tobacco Conumption and Risk of Spontaneous Abortion. Public Health Report; Volume 124, pp. 317-322.

BPS (2015) Survei Sosial Ekonomi Nasional. Dalam: Jakarta: BPS.

Carmichael, S. et al (2005) National Birth Defects Prevention Study. Hypospadias and maternal exposures to cigarette smoke. Paediatr Perina Epidemiol, pp. 19:406-12.

Cui, X. et al (2016) Potential effect of smoking on semen quality through DNA damage and the downregulation of Chk1 in sperm. Molecular Medicine Reports, pp. 753-761.

Cunningham, F. G. et al (2010) Williams Obstetrics 23rd Edition. Dalam: Abortion. USA: McGraw-Hill.

Darwin, M (2007) Perilaku Merokok dan Pengalaman Regulasi di Berbagai Negara. Populasi, 18(2), pp. 201-215.

Department of Health and Human Services (2006) The Health Consequences of Involuntary Exposure to Tobacco Smoke - A Report of the Surgeon General, Atlanta: National Library of Medicine Cataloging.

D e pkes R I, ( $\left.\begin{array}{llll}2 & 0 & 1 & 6\end{array}\right)$ [ O n lin e ] [Diakses 23 Februari 2018].

Depkes RI, (2016) Hari Tanpa Tembakau Sedunia 2016: Suarakan Kebenaran, Jangan Bunuh DIrimu dengan Candu Rokok. [Online] A v a i 1 a b 1 a $t$ : http://www.depkes.go.id/article/print/16 $\underline{060300002 / \mathrm{htts}-2016 \text {-suarakan- }}$ kebenaran-jangan-bunuh-dirimud engan-candu-rokok.h tm [Diakses 23 Februari 2018].

Economides, D. \& Braithwaite, J (1994) Smoking, Pregnancy and the Fetus. $J R$ Soc Health, pp. 198-201.

Feldkamp, M. et al (2014) National Birth Defects Prevention Study. Self-reported maternal cigarette smoke exposure during the periconceptional peridode and the risk for omphalocele. Paediatr Perinat Epidemiol, pp. 28:67-73.

Gardosi, J. O (2005) Prematurity and fetal growth restriction. Early Human Development, 81(1), pp.43-49.

Gilman, E. S. et al (2009) Parental smoking and adolescent smoking initiation: an intergenerational perspective on tobbaco control. Pediatrics, 123(2), pp. e274-e281.

Gocze, P., Szabo, I. \& Freeman, D (1999) Influence of nicotine, cotinine, anabasine and cigarette smoke extract on human granulosa cell progesterone and estradiol synthesis. Gynecol Endocrinol; 13(4), pp. 266-272.

Harlev, A. et al (2015) Smoking and Male Infertility: An Evidence-Based Review. World J Mens Healt, pp. 143-160.

John, L. L. et al (2011) Parental and household smoking and the increased risk of bronchitis, bronchiolitis and other lower respiratory infections in infancy: systematic review and meta-analysis. Respiratory Research, Volume 125, pp. 111.

Judith R, B., Barbara J, S. \& Adetokunbo O, L (2003) Improving Birth Outcome: Meeting the Challenge in the Developing World. Washington DC: National Academy of Sciences.

Kliman, H (1999) Uteroplacental blood flow: the story of decidualization, menstruation, and trophoblast invasion. Am J Pathol, p. 1759-1768.

Lee, B.-E.et al (2011) Secondhand smoke exposure during pregnancy and infantile neurodevelopment. Enviromental 
Research; Volume 111, Issue 4, pp. 539-544.

Leonardi-Bee, J., Britton, J. \& Venn, A (2011) Secondhand Smoke and Adverse Fetal Outcome in Nonsmoking Pregnant Women: A Meta-analysis. Pediatrics, Volume 127, pp. 734-741.

Malik, S., Cleves, M. \& Honein, M (2008) Maternal smoking and congenital heart defects.. Pediatrics, pp. 121:e810-6.

Menon, R. et al (2011) Cigarette smoke induces oxidative stress and apoptosis in normal term fetal membranes. Placenta, Volume 32, pp. 317-322.

Miller, E. et al (2009) Maternal exposure to tobacco smoke, alcohol and caffeine and risk of anorectal atresia: National Birth Defects Prevention Study 1997-2003. Paediatr Perinat Epidemiol, pp. 29:9-17.

Perkins, S (2000) Comparison of serum progesterone as an indicator of pregnancy nonviability in spontaneously pregnant emergency room and infertility clinic patients populations. Fertil Steril, p. 73:499-504.

Pineles, B. L., Park, E. \& Samet, J. M (2014) Systematic Review and Meta-Analysis of Miscarriage and Maternal Exposure to Tobacco Smoke During Pregnancy. Am J Epidemiol; 179 (7), pp. 807-823.

Singh, J. \& Scott, L (1984) Threshold for carbon monoxide induced fetotoxicity. Teratology, pp.30(20):253-257.

Spitz, I (2003) Progesterone antagonists and progesterone receptor modulators, an overview. Steroids, p. 68:981-983.

Svanes, C. et al (2017) Father's enviroment before conception and asthma risk in his children: a multigeneration analysis of the Respiratory Health In Northen Europe study. Int J Epidemiol, 46(1), pp. 235-245.

Verma, U., Goharkhay, N. \& Beydoun, S (2006) Conservative management of preterm premature rupture of membranes between 18 and 23 weeks of gestation meternal and neonatal outcome.. Ejog, 128(1-2), pp. 119-124.

Wang, M., Wang, Z., Zhang, M. \& Zhao, Z (2014) Maternal passive smoking during pregnancy and neural tube defects in offspring: a meta-analysis. Arch Gynecol Obstet, pp. 289:513-21.

WHO South East Asia (2011) Global Adult Tobacco (GAT) Survey: Indonesia Report 2011, New Delhi: WHO Library Cataloguing in Publication Data.

WHO (2015) Tobacco control in Indonesia. $\left[\begin{array}{llllllll} & \mathrm{O} & \mathrm{n} & \mathrm{l} & \mathrm{i} & \mathrm{n} & \mathrm{e} & \text { ] }\end{array}\right.$ A v a i l a ble a $\mathrm{t}$ : http://www.who.int/tobacco/about/part ners/bloomberg/idn/en/

Wilson, K. M. et al (2013) Secondhand Tobacco Smoke Exposure and Severity of Influenza in Hospitalized Children. The Journal of Pediatrics, 162(1), pp. 16-21.

Wong-Gibbons, D., Romitti, P. \& Sun, L (2008) Maternal periconceptional exposure to cigarette smoking and alcohol and esophageal atresia +/- tracheoesophageal fistula.. Birth Defects Res A Clin Mol Teratol, pp. 82:776-84.

Yogman, M. \& Garfield, C. F (2016) Fathers' Roles in the Care and Development of Their Children: The Role of Pediatricians. Pediatrics; Volume 138, number 1, pp. e1e16.

Zhang, B., Jiao, X., Mao, L. \& Xue, J (2011) Maternal cigarette smoking and the associated risk of having a child with orofacial clefts in China: a case-control study. J Craniomaxillofac Surg, pp. 39:3138.

Zhang, J., Savits, D., Schwingl, P. \& Cai, W (1992) A case-control study of paternal smoking and birth defects.. Int J Epidemiol, pp. 21:273-8 